\title{
Development of Animation Attitude Scale (AAS): Validity And Reliability Study
}

\author{
Derya ÇINAR *1 (D) Hakan KURT ${ }^{2}$ \\ ${ }^{1}$ Necmettin Erbakan University, Faculty of Education, Konya, Turkey, deryacinar42@gmail.com \\ ${ }^{2}$ Necmettin Erbakan University, Faculty of Education, Konya, Turkey, kurthakan1@gmail.com \\ * Corresponding Author: deryacinar42@gmail.com
}

\begin{tabular}{|c|c|}
\hline Article Info & Abstract \\
\hline $\begin{array}{l}\text { Received: } 10 \text { September } 2019 \\
\text { Accepted: } 16 \text { October } 2019\end{array}$ & $\begin{array}{l}\text { The aim of this study is to develop an attitude scale that can determine } \\
\text { the attitudes of the undergraduate students to the use of animation in } \\
\text { science education. The study group of this research consisted of } 240 \\
\text { students enrolled in the } 3 \text { rd and } 4 \text { th grades in the primary and science } \\
\text { education department. } 124 \text { of the participants were primary student } \\
\text { teachers, } 116 \text { were science student teachers and the average age was } \\
20.6 \text { years. Factor structure of AUASSI attitude scale with Exploratory }\end{array}$ \\
\hline $\begin{array}{l}\text { Keywords: Animation use, attitude, } \\
\text { scale development, factor analysis }\end{array}$ & $\begin{array}{l}\text { Factor Analysis (EFA) was determined then tested with Confirmatory } \\
\text { Factor Analysis (CFA). Inter-item correlations, item-test correlations, } \\
\text { Cronbach's alpha coefficients, test-retest reliability, Keiser-Meyer-Olkin }\end{array}$ \\
\hline DOI: 10.18009/jcer.617943 & $\begin{array}{l}(\mathrm{KMO}) \text { and Barlett's test are included. As a result of the analyzes, the } \\
\text { scale was determined as two dimensions as interest and interaction. }\end{array}$ \\
\hline Publication Language: English & $\begin{array}{l}\text { The results of this study demonstrate that the AUASSI attitude scale is } \\
\text { valid and reliable instrument for undergraduate students. }\end{array}$ \\
\hline
\end{tabular}

\section{Introduction}

The term "Information and Communication Technologies" means the transmission, storage, discovery, sharing of or having access to information (UNESCO [United Nations Educational, Scientific and Cultura], 2006). It is defined as innovative ways of providing global access to information for individuals in need of lifelong learning (Odabas1 et al., 2006). With the beginning of using this technology in schools, it is expected to go beyond the borders of class and to make learning independent of time and space, leading to system-wide changes in the school (Watson, 2001; Loveless, 2003; Tubin, Mioduser, Nachmias \& Baruch, 2003). However, an important aspect of these changes includes its use in learning-teaching processes. 
Teachers and students report that they experience difficulties in learning and teaching of science and technology classes. The main reason behind these difficulties is that most of the science and technology concepts are abstract and that the concepts used in daily life are used in different meanings in science instruction (Taber, 2002). As most of the science and technology concepts are abstract and students have difficulties in understanding these concepts, it can be helpful to teach these concepts by reifying them through the use of concrete aids of instruction for students to learn them (Atılboz, 2004).

The computer is an important information, communication and technological tool used in learning and teaching environments, supporting instructional process, increasing student motivation and students can make use of it depending on their personal learning speed. It was found that students using technological means such as video displays, simulations and animations on the computer can achieve permanent learning (Demircioğlu \& Geban, 1996; Celen et al., 2011) and that they enjoy using these technological tools (Byers, 1997). Animation is one of these technological tools. Due to their dynamic outlook and capacity to animate abstract events, animations can exert positive influence on learning (Lewarter, 2003; Lowe, 2003).

\section{Theoretical Framework}

With the changes made in elementary and secondary education programs, it was intended to make more effective use of information technologies and it was emphasized that incorporation of simulations, graphs, voices and models into classes can play an important role in the understanding of concepts and processes (URL1, 2008). In science classes, some experiments cannot be performed due to different reasons such as expensive materials, long time and huge amount of effort required for preparation and implementation and presence of dangerous materials in laboratory environments. Computer animations and simulations enable students to observe experiments that cannot be done in a laboratory setting (Tascl, Yaman \& Soran, 2010). Materials created in the computer can generate an active learning environment for students and constitute an important stage for meaningful learning to occur.

Mayer and Moreno (2002) stated that integration of multi-media technologies fosters cognitive development. Properly designed multimedia-based tools are one of the factors affecting learning (Najjar, 1996). In many studies, it has been reported that multimedia-based approaches more effectively contribute to student learning than traditional strategies (Jereb 
\& Smitek, 2006). Recent developments in computer technologies have contributed to the development of multi-media technologies extensively used by educators in the design of educational tools. However, the application of suitable technologies for the design of multimedia-based educational tools has not been adequately researched (Mayer, 2008; Tabbers, Martens \& Van Merrienboer, 2004).

One of the multi-media technologies extensively used in learning environments is animations. Animation is a technological option that can be used in many different areas of education by presenting pictures and graphs within scenarios. Animation is especially preferred in the explanation of complex concepts. Through animations, it can be shown how figures or color appear, disappear or change. These changes can be in the form of either graphs or pictures (Laybourne, 1998). If pictures and caricatures are motionless, then they cannot be considered animations because animations should not stay continuously moving or stable. Animation is an animated moving picture to illustrate the movement of objects (Burke et al., 1998). When animations are a part of an applied strategy in education, they can also be used to give feedback to students (Karacöp, 2010). Animation is defined as a moving picture generally integrated with the parts of known media such as caricatures or 3D or three dimensional visual real simulation, video, graph, voice and produced by computer (Mayer \& Anderson, 1992; Szabo \& Poohkay, 1996).

Research has reported that the use of animations in education can lead to significant increases in students' attitudes to a course and academic achievement (Cepni et al., 2006; Katırcıoğlu \& Kazanc1, 2003; Powel, Aeby \& Carpenter-Aeby, 2003). When research focusing on animations is reviewed, it is seen that they make positive contributions to students' academic achievement in the topic of force and movement, retention of information and scientific process skills (Dasdemir \& Doymus, 2012), academic achievement of secondary school students in terms of learning operations with letter-based terms (Aktümen \& Kacar, 2003), teaching the topic of cell to secondary school students (Aykanat, Dogru \& Kalender, 2005). Moreover, it was found that students have positive attitudes towards such instructional materials (Gökhan, 2011) and they enable pre-service math teachers to realize meaningful learning and they are liked by students (Bukova-Güzel \& Cantürk-Günhan, 2010).

When international research is examined, it is seen that animations have positive effects on elementary school students' academic achievement (Santos, 2009) and on high 
school students' concept learning (Elmstrom Klenk, 2011). In the literature, it is clearly seen that many researchers are of the opinion that animations reify abstract concept particularly in science and math classes, promoting students' learning (Lipeikiene \& Lipeika, 2006). Scholars argue that creating visualizations of abstract concepts can be a challenging cognitive process for science learners (Ong \& Mannan, 2004; Dalacosta, Kamariotaki-Paparrigopoulou, Palyvos \& Spyrellis ,2009).

When computer-assisted instructional applications are examined in the literature, it is seen that factors such as motivation, attitude and physical inadequacies affect application process, quality of the teacher and academic achievement. The most important of these factors is attitude. In a general sense, attitude is defined as an individual's prejudice against a specific object. In order to be able to understand what an individual's attitude towards an object is, the individual's reactions against this object need to be observed in different environments. Attitude refers; at the same time, to resistant to change (Morgan, 1999). It was reported that computer-assisted science instruction at schools positively affected interest, attitude and academic achievement in science classes (Cekbas et al., 2003; Yenice, 2003). The more students' interaction with technology is increased, the more their technological literacy will improve. The scale is aimed to bring the literature to the national and international level.

\section{Method}

The current study is a scale development study. In scale development studies, the item / question pool for the scale was created in Likert type format (DeVellis, 2003). While designing the items, care has been taken to ensure that the articles are simple and understandable and that one item does not have more than one expression of judgment and thought (Ekici, Taşkın-Ekici \& Kara, 2012). In the next step, expert comment was applied for the pool of substances formed. Experts assessed the necessity, clearness and specificity of the questions. Content validity was evaluated with expert comment. The scale, which was shaped according to expert opinion, was applied to the draft sample group. Trial implementation is important for the performance of the scale. The sample should represent the target group. After the implementation of the draft, the validity and reliability analyzes of the scale were evaluated and finalized (DeVellis, 2003). 


\section{Study group}

Cross-section sampling method was used. The study group of the current research is comprised of 240 third and fourth year students enrolled in the departments of classroom and science teacher education. Of the participants, 124 are from the department of classroom teacher education and 116 are from the department of science teacher education and their mean age is 20.6 .

\section{Scale}

The Scale of Attitude towards the Use of Animation in Science Instruction (AUASSI) was developed by the researchers. In the scale development process, first literature on the use of animation was reviewed and it was found that there is no scale to evaluate the attitudes towards the use of animations. In this connection, the Animation Opinion Scale (Dasdemir \& Doymus, 2012) was found in the literature and some items from this scale were taken into the item pool of the current study after making some amendments to them. Yet, as these items were not found to be adequate, the exploratory sequential mixed method was employed in the current study. In this method, first data related to the research problem are collected. The collected data are analyzed and interpreted. Besides offering many advantages to researchers, this method is particularly suggested to be used in scale development studies (Creswell, 2014). Thus, in the current study, first interviews were conducted with 20 students enrolled in the third and fourth grades of the departments of classroom teacher and science teacher education and in this way, attitude items were constructed. On the basis of the collected data, a total of 35 5-point Likert items (1: Completely agree, 2: Agree, 3: Undecided, 4: Disagree, 5: Completely disagree) were constructed. In order the establish the content and face validity of the scale, it was checked by 3 field experts, 1 measurement and evaluation expert, 1 Turkish language expert and 1 English language expert and necessary corrections were made. On the basis of expert opinions, 4 items were decided to be discarded from the scale. As a result, in the final form of the scale 31 items (15 positive, 16 negative) were kept.

In order to establish the construct validity of the scale, it was administered to the participants. Following the application, Exploratory Factor Analysis (EFA), then Confirmatory Factor Analysis (CFA) were conducted and construct validity was tested. For 
the reliability of the scale, internal consistency coefficient was examined. In the data analysis, SPSS 18.0 was used for exploratory factor analysis and Lisreal 8.7 program was used for confirmatory factor analysis. EFA is one of the statistical techniques extensively used to produce few meaningful and independent factors from a large number of variables. CFA is a technique used to determine whether the component groups involved in the factors are adequately represented by these factors (Büyüköztürk, 2010; Tabachnick \& Fidell, 2007). In the current study, CFA was conducted over the same data set to support the factors determined with EFA.

\section{Findings}

In the presentation of the findings, first findings obtained from EFA and CFA analyses conducted to establish validity are presented. Then the findings obtained related to convergence and discrimination validity are presented. Following the findings concerning validity, findings related to reliability are presented.

First it was investigated whether the data collected from 240 students are suitable for exploratory factor analysis (Field, 2009). EFA was calculated over the responses given to 31 items. In the analysis, first test results related to Kaiser-Mayer-Olkin (KMO) and Barlett's Sphericity Test (BST) were analyzed. As a result of EFA, KMO coefficient was found to be .888 and when the BTS results were examined (Chi square $=2964,849 ; \mathrm{df}=465 ; \mathrm{p}=.000$ ), it was found that the data were suitable for factor analysis and that EFA could be conducted (Cokluk, Şekercioğlu \& Büyüköztürk, 2010; Field, 2009).

In the factor analysis, principal components analysis was performed with 31 items. The criteria used to determine the number of factors are eigenvalue higher than 1 , the rate of the total variance explained and scree plot (Field, 2009). Two-factor structure of AUASSI can explain $48.94 \%$ of the total variance. The investigation of the scree plot also supports the twofactor structure (Figure-1). Of the scale items, 16 were found to have similar item loadings in more than one factor; that is, they are overlapped (Cokluk et al., 2010) thus, it was decided to discard these items from the scale. Moreover, items with loadings lower than 0.4 were excluded from the scale. In the determination of the factor loadings of the items, the values proposed by Field (2009) were taken as a reference. According to these values, the cut-off value for a sampling of 100 participants is .512, for a sampling of 200 participants, it is .364 . Therefore, in the current study for the sampling consisted of 240 participants it was set to be 
.40. According to Pallant (2007); for the table of the common variance, values under .3 do not comply with the other items in their factor. In this line, the table of common variance was checked in each exclusion and values under .3 were thus discarded.

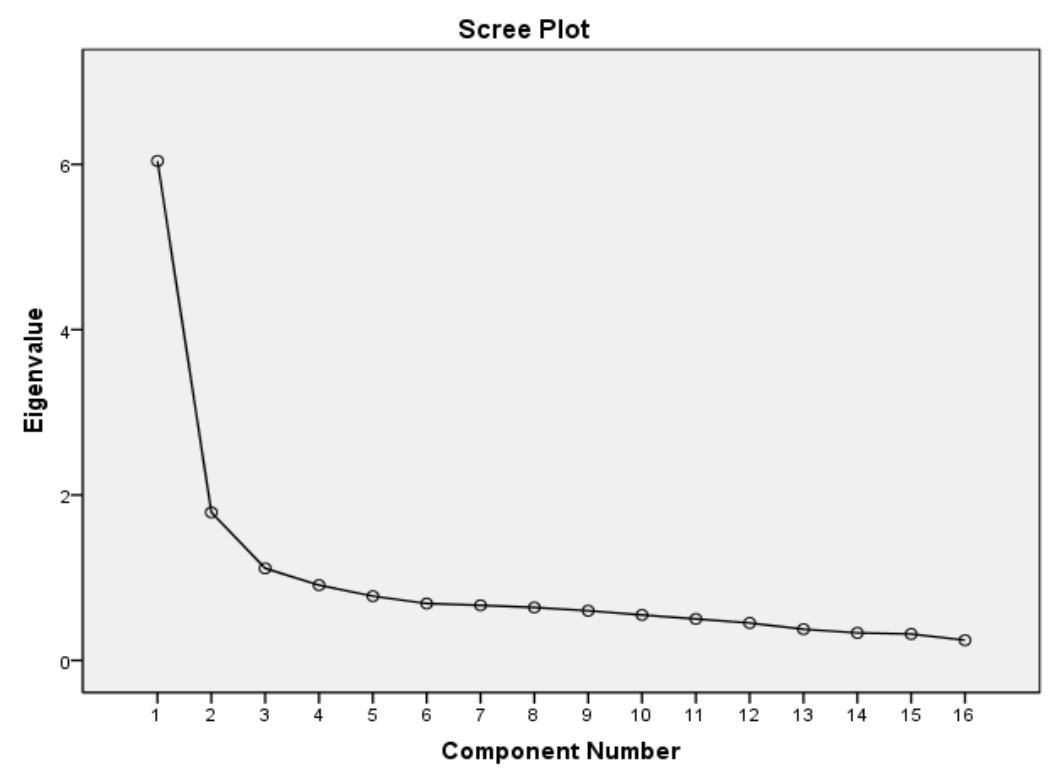

Figure 1. Scree Plot

As a result of the operations conducted through Varimax rotation technique, the items unsuitable were deleted. The common variance for the two factors was found to be $26.27 \%$ and $22.67 \%$. In the field of educational sciences, a total variance value explained between $40 \%$ and $60 \%$ is considered to be adequate and for a factor to be considered significant, at least $5 \%$ of the total variance explained should come from it (Cokluk et al., 2010). Therefore, the total variance explained in the current study is $54.18 \%$ and it is acceptable. Following Varimax y-axis rotation, the scale was found to be made up of 16 items subsumed under two factors. The two factors are named as interest and interaction. The interest factor has 9 items and item loadings of this factor vary between .47 and .81 . The interaction factor is comprised of 7 items and item loadings of this factor vary between .58 and .74. In addition to these, factor loading of each item varies between .42 and .73 and these values are considered to be good (Field, 2009). 
Table 1. Factor loading values

\begin{tabular}{|c|c|c|c|}
\hline \multirow[t]{2}{*}{ Items } & \multirow{2}{*}{$\begin{array}{l}\text { Common } \\
\text { Variance }\end{array}$} & \multicolumn{2}{|l|}{ Factor Loading Values } \\
\hline & & Factor 1 & Factor 2 \\
\hline 5 & ,465 & 819 & \\
\hline 4 & 616 & ,770 & \\
\hline 6 & 691 & 743 & \\
\hline 10 & 609 & 691 & \\
\hline 22 & 457 & 634 & \\
\hline 8 & ,521 & 618 & \\
\hline 11 & 481 & ,550 & \\
\hline 2 & ,622 & ,549 & \\
\hline 18 & ,347 & ,471 & \\
\hline 20 & ,250 & & ,741 \\
\hline 21 & ,486 & & 726 \\
\hline 12 & ,581 & & 697 \\
\hline 19 & ,587 & &,- 697 \\
\hline 16 & ,501 & & ,586 \\
\hline 23 & 401 & & ,584 \\
\hline 26 & 215 & & 450 \\
\hline Eigenvalue Total & 26,276 & & \\
\hline $\begin{array}{l}\text { Explained total } \\
\text { variance }\end{array}$ & 48,945 & Alpha value & 79 \\
\hline
\end{tabular}

Then, the reliability of AUASSI was examined in two dimensions that are consistency and persistence. The consistency of the scale was tested through Cronbach Alpha internal coefficient and its persistency was tested by using test retest technique including the readministration of the scale to 90 students two weeks after the first administration. For the whole scale, Cronbach Alpha value was found to be .79 . The reliability value for the "interest" factor was found to be .80 and it was found to be .77 for the "interaction" factor. All of the internal consistency values were found to be higher than .70, indicating that reliability values of the scale yield consistent data.

Secondly, in relation to construct validity, a total of 130 participants from the top $27 \%$ and bottom $27 \%$ were selected (65 participants for each) in order to determine how much the 
scale distinguish those having high level of the characteristic from those having low level of this characteristic the scale intends to measure. By looking at whether each sub-dimension distinguishes these two groups, t-test was run to determine that the dimensions significantly distinguish the bottom group and the top group. As the scores taken by the participants from AUASSI exhibited a normal distribution, independent t-test was used and the results are presented in Table 2.

Table 2. Item discrimination results according to the top $27 \%$ and the bottom $27 \%$ formed on the basis of sub-dimension and total scores of AUASSI

\begin{tabular}{|c|c|c|c|c|c|c|c|c|}
\hline AUASSI & Items & $\begin{array}{l}\text { Bottom } \\
\text { top } \\
\text { groups }\end{array}$ & $\mathrm{N}$ & $\overline{\mathrm{X}}$ & $\mathrm{Sd}$ & $\mathrm{t}$ & $\mathrm{df}$ & $\mathrm{P}$ \\
\hline \multirow{18}{*}{ Interest } & \multirow[t]{2}{*}{2} & Bottom & 65 & 3,5385 & 81157 & $-12,079$ & 128 &, $000^{*}$ \\
\hline & & Top & 65 & 4,8615 & ,34807 & & & \\
\hline & \multirow[t]{2}{*}{4} & Bottom & 65 & 3,9231 & 1,00480 & $-7,642$ & 128 &, $000^{*}$ \\
\hline & & Top & 65 & 4,9231 & ,32150 & & & \\
\hline & \multirow[t]{2}{*}{5} & Bottom & 65 & 3,6154 & ,82334 & $-10,236$ & 128 &, $000^{*}$ \\
\hline & & Top & 65 & 4,8154 & ,46410 & & & \\
\hline & \multirow[t]{2}{*}{6} & Bottom & 65 & 3,7077 & 84267 & $-10,849$ & 128 &, $000^{*}$ \\
\hline & & Top & 65 & 4,9077 & ,29171 & & & \\
\hline & \multirow[t]{2}{*}{8} & Bottom & 65 & 3,9385 & ,78813 & $-8,638$ & 128 &, $000^{*}$ \\
\hline & & Top & 65 & 4,8615 & ,34807 & & & \\
\hline & \multirow[t]{2}{*}{10} & Bottom & 65 & 3,8000 & ,86963 & $-10,168$ & 128 &, $000^{*}$ \\
\hline & & Top & 65 & 4,9385 & ,24219 & & & \\
\hline & \multirow[t]{2}{*}{11} & Bottom & 65 & 3,5385 & ,90272 & $-10,659$ & 128 &, $000^{*}$ \\
\hline & & Top & 65 & 4,8462 & ,40430 & & & \\
\hline & \multirow[t]{2}{*}{18} & Bottom & 65 & 3,3385 & 85288 & $-5,648$ & 128 &, $000^{*}$ \\
\hline & & Top & 65 & 4,2615 & 1,00432 & & & \\
\hline & \multirow[t]{2}{*}{22} & Bottom & 65 & 4,1385 & ,80772 & $-3,451$ & 128 &, $001^{*}$ \\
\hline & & Top & 65 & 4,5846 & ,65889 & & & \\
\hline \multirow{14}{*}{ Interaction } & \multirow[t]{2}{*}{12} & Bottom & 65 & 3,1846 & 1,08818 & $-10,318$ & 128 &, $000^{*}$ \\
\hline & & Top & 65 & 4,7385 & ,53843 & & & \\
\hline & \multirow[t]{2}{*}{16} & Bottom & 65 & 3,0462 & ,92586 & $-4,215$ & 128 &, $000^{*}$ \\
\hline & & Top & 65 & 3,7692 & 1,02727 & & & \\
\hline & \multirow[t]{2}{*}{19} & Bottom & 65 & 2,9231 & 1,10832 & 3,694 & 128 &, $000^{*}$ \\
\hline & & Top & 65 & 2,2308 & 1,02727 & & & \\
\hline & \multirow[t]{2}{*}{20} & Bottom & 65 & 3,3692 & 1,00886 & $-9,483$ & 128 &, $000^{*}$ \\
\hline & & Top & 65 & 4,6923 & ,49759 & & & \\
\hline & \multirow[t]{2}{*}{21} & Bottom & 65 & 3,0923 & 1,07126 & $-10,097$ & 128 &, $000^{*}$ \\
\hline & & Top & 65 & 4,6308 & ,60128 & & & \\
\hline & \multirow[t]{2}{*}{23} & Bottom & 65 & 2,8923 & 1,16086 & $-9,758$ & 128 &, $000^{*}$ \\
\hline & & Top & 65 & 4,5385 & 70880 & & & \\
\hline & \multirow[t]{2}{*}{26} & Bottom & 65 & 2,6923 & ,99880 & $-6,754$ & 128 &, $000^{*}$ \\
\hline & & Top & 65 & 3,9385 & 1,10223 & & & \\
\hline \multirow{2}{*}{$\begin{array}{l}\text { Interest and } \\
\text { interaction }\end{array}$} & \multirow[b]{2}{*}{ Total } & Bottom & 65 & 54,7385 & 5,63271 & $-22,161$ & 128 &, $000^{*}$ \\
\hline & & Top & 65 & 71,5385 & 2,37221 & & & \\
\hline
\end{tabular}

${ }^{*} \mathrm{p}<0,01$ 
When the differences between the item mean scores of the bottom and top groups constructed according to interest dimension, interaction dimension and whole scale scores for AUASSI were compared with $\mathrm{t}$-test, the items were found to be significant $<0,01)$, showing that it can distinguish the pre-service teachers interest and interaction attitudes towards the use of animation.

Third, in order to check whether the two-factor model obtained from CFA for AUASSI complies with the data (Sümer, 2000; Cokluk et al., 2010), confirmatory factor analysis (CFA) was conducted. For this purpose, the data set obtained from 240 participants used for EFA was analyzed by using Lisrel 8.7 program package. The path scheme and goodness-of-fit statistics were calculated for two factors including 16 items. The path scheme; with standardized solutions, shows the loading of each item in the two factors.

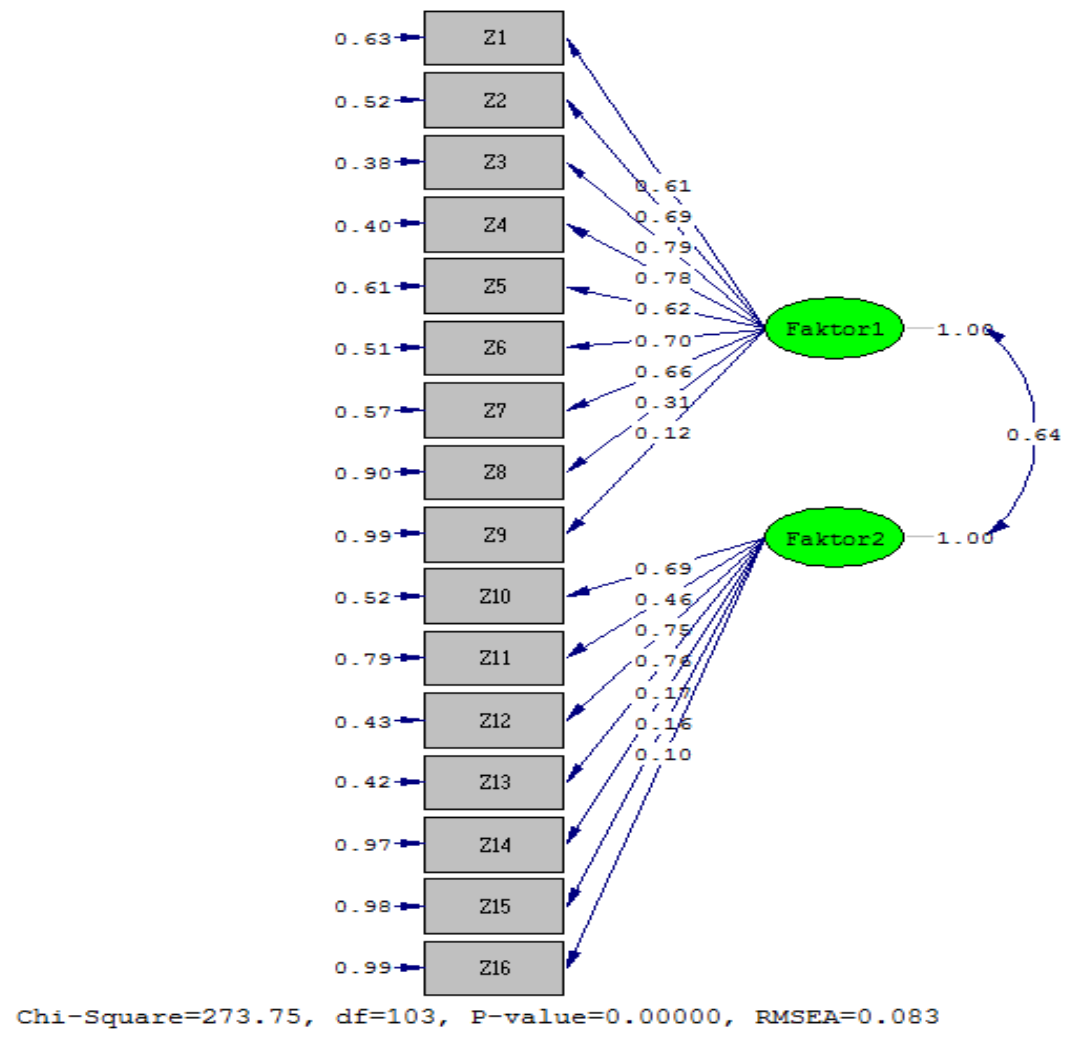

Figure 2. Standardized model

Following standard solutions, $t$ values between the factors and the items were examined. Absence of red arrow for $t$ values shows that all the items are significant at the level of .05 (Jöreskog \& Sörbom, 1996). Maximum likelihood estimates are between 0.31 and 0.75 and all the $t$ values, except for items 9 and 16, are significant at the level of 0.05 . The two 
factors confirm each other; moreover, error variances are between 0.35 and 0.95 . Kline (2005) states that error variance should not exceed 0.90. In our scale, item 9 in the first factor and item 7 in the second factor seem to be erroneous. Yet, these items were decided to be kept in the scale in light of expert opinions. Thus, factor loadings of each item seem to be at an acceptable level.

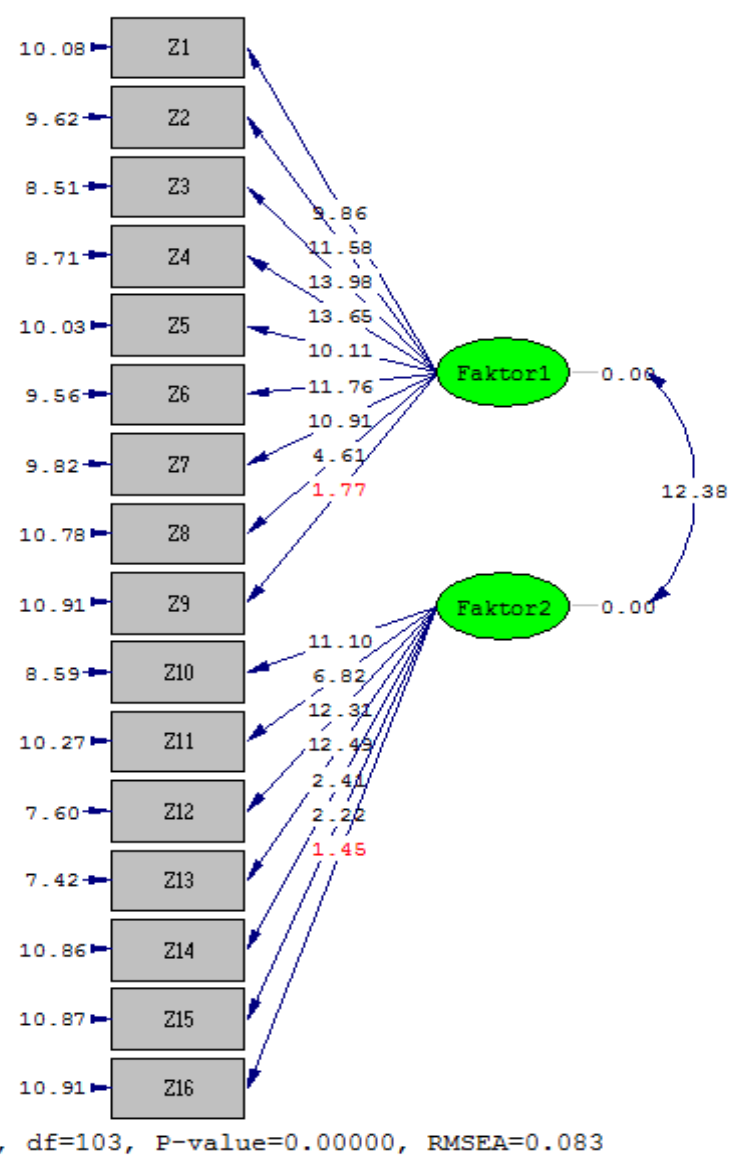

Chi-Square $=273.75, d f=103, P-$ value $=0.00000$, RMSEA $=0.083$

Figure 3. Model showing $t$ values

Table 3. Goodness-of-fit Indices Value Intervals and Values of the Model

\begin{tabular}{lllll}
\hline $\begin{array}{l}\text { Goodness- } \\
\text { of-fit } \\
\text { indices }\end{array}$ & Perfect & Acceptable & $\begin{array}{l}\text { Values of } \\
\text { the } \\
\text { Model }\end{array}$ & Result \\
\hline $\mathrm{x}^{2} / \mathrm{df}$ & $\leq 3$ & $\leq 3$ & 2.65 & perfect \\
\hline RMSEA & $\leq, 05$ & $\leq, 08$ & .08 & acceptable \\
\hline SRMR & $\leq, 05$ & $\leq, 08$ & .08 & acceptable \\
\hline GFI & $\geq, 95$ & $\geq, 90$ & .87 & acceptable \\
\hline AGFI & $\geq, 90$ & $\geq, 85$ & .83 & acceptable \\
\hline CFI & $\geq, 95$ & $\geq, 90$ & .93 & acceptable \\
\hline NNFI & $\geq, 95$ & $\geq, 90$ & .91 & acceptable \\
\hline
\end{tabular}


As a result of CFA, the goodness-of-fit values were found to be $x^{2}=273.75$ ( $\mathrm{df}=103$, $\mathrm{p}=, 000), \mathrm{x}^{2} / \mathrm{df}=2.65, \mathrm{RMSEA}=0.08, \mathrm{SRMR}=0.08, \mathrm{GFI}=0.87, \mathrm{AGFI}=0.83, \mathrm{CFI}=0.93, \mathrm{NNFI}=0.91$. According to these values, though GFI and AGFI values seem to be a bit lower that the acceptable value, RMSEA, SRMR, CFI and NNFI values are acceptable values (Table 2). This indirectly obtained model shows that the model factors are confirmed with the data (Cokluk et al., 2010; Tabachnick \& Fidell, 2001).

The persistency of the scale was tested by using test retest technique. For test retest, the scale was re-administered to 90 students having been in the study group while the reliability and validity studies of the scale were conducted two weeks after the first administration. The data obtained through the test retest technique were compared with the data obtained from the first administration through Pearson product-moment correlation. As a result of the correlation analysis, the correlation coefficient was found to be .82 . This is a considerably high correlation, indicating that the persistency of the scale is high. The correlations between AUASSI and the factors were tested with Pearson-product moment correlation.

Table 4. Correlation values between the AUASSI's factors

\begin{tabular}{rllll}
\hline Dimensions & Correlation & Interest & Interaction & General \\
\hline Interest & Pearson Correlation & 1 &, $530^{* *}$ &, $899^{* *}$ \\
\cline { 2 - 5 } & Sig. (2-tailed) & &, 000 &, 000 \\
\cline { 2 - 5 } & $\mathrm{N}$ & 240 & 240 & 240 \\
\hline \multirow{3}{*}{ Interaction } & Pearson Correlation &, $530^{* *}$ & 1 &, $848^{* *}$ \\
\cline { 2 - 5 } & Sig. (2-tailed) &, 000 & &, 000 \\
\cline { 2 - 5 } & $\mathrm{N}$ & 240 & 240 & 240 \\
\hline \multirow{3}{*}{ General } & Pearson Correlation &, $899^{* *}$ &, $848^{* * *}$ & 1 \\
\cline { 2 - 5 } & Sig. (2-tailed) &, 000 &, 000 & \\
\cline { 2 - 5 } & $\mathrm{N}$ & 240 & 240 & 240 \\
\hline \multirow{2}{*}{$* \mathrm{p}<.01$} & & &
\end{tabular}

When Table 4 is examined, it is seen that the correlations between the total score of the scale and the factor scores are ranging between .84 and .89 and significant at the level of .01 . The correlation between the factor scores is .53 and significant at the level of .01 . These findings show that compliance and correlation between the factors are high. As a result, it can be claimed that AUASSI with acceptable validity and reliability was developed. The data obtained in relation to validity and reliability show that AUASSI can be reliably used to measure pre-service teachers' attitudes towards the use of animations. 


\section{Discussion and Conclusion}

The current study aimed to develop a scale to measure pre-service teachers' attitudes towards the use animations. For this purpose, the existing scales and the relevant literature were examined, the opinions of the experts in the field were sought and interviews were conducted with 20 students and thus the item pool was constructed. The developed scale emerged as a 31-item five-point Likert scale. Then this scale was administered to 240 individuals and its validity and reliability studies were conducted. EFA revealed that the scale could explain $48.94 \%$ of the variance in the scale. For the two factors, the common variance was found to be $26.27 \%$ and $22.67 \%$. After the EFA, a construct comprised of 2 factors and 16 items was obtained. In line with the expert opinions and literature review, the first factor was named as "interest" and the second factor was named as "interaction". In the first factor, there are 9 items to elicit pre-service teachers' interest about the use of animations. Of these 9 items, 6 include positive statements and 3 include negative statements. In the second factor, there are 7 items to elicit pre-service teachers' interactions towards the use of animations. Of these 7 items, 2 include positive statements and 5 include negative statements. The construct validity of AUASSI was tested with EFA and CFA. As a result of EFA, 15 items were discarded and two-factor 16-item 5-point Likert type AUASSI was produced. The factor loadings of the items in the 2 factors range from .47 to .81 . Item loadings in the interest dimension of the scale vary between .47 and .81 . Item loadings in the interaction dimension vary between .58 and .74 . In addition, common factor loading of each item vary between .42 and .73 and these values are considered to be good (Field, 2009). The interest and interaction internal consistency coefficients were found to be .80 and .77 , respectively. The general internal consistency coefficient of the scale was found to be .79, which is an acceptable level.

The factors derived from EFA were tested with CFA. As a result of CFA, goodness-offit values were found to be $x^{2}=273.75(\mathrm{df}=103, \mathrm{p}=, 000), \mathrm{x}^{2} / \mathrm{df}=2.65, \mathrm{RMSEA}=0.08$, SRMR=0.08, $\mathrm{GFI}=0.87, \mathrm{AGFI}=0.83, \mathrm{CFI}=0.93, \mathrm{NNFI}=0.91$. RMSEA, SRMR, CFI and NNFI values are acceptable values. They show that these indirectly obtained model factors are confirmed with the data (Cokluk et al., 2010; Tabachnick \& Fidell, 2001). As a result of CFA, t values of items and factors in the latent variable were found to be ranging from 1.45 to 13.98 and except for 2 items, it is significant for 14 items at the level of .05. Yet, these two items were 
decided to be kept in the scale as in light of expert opinions. According to Jöreskog and Sörbom (1996), absence of red arrow related to $t$ value shows that all the items are significant at the level of .05.

As a result of this study, it can be maintained that a reliable and valid scale was developed to explore pre-service teachers' attitudes towards the use of animations. Researchers can use this scale to find the weak and strong sides of pre-service teachers' attitudes towards the use of animations. Further research may look at teachers and preservice teachers' attitudes towards the use of animations in relation to different variables. Moreover, further research can be conducted to explore the effectiveness of animation activities to enhance classes.

\section{References}

Acten, M., \& Kachar, A. (2003). The role of computer-assisted instruction in teaching 8th grade letter-based operations and evaluation of students' views on computerassisted instruction. Kastamonu Education Journal, 11 (2), 339-358.

Atılboz, N.G. (2004). High school 1st grade students' level of understanding and misconceptions about mitosis and meiosis. Gazi University Journal of the Faculty of Education, 24 (3), 147-157.

Aykanat, F., Correct, M., \& Kalender, S. (2005). The effect of science teaching with computer assisted concept maps on student achievement. Kastamonu Education Journal, 13 (2), 391-400.

Bukova-Güzel, E., \& Cantürk-Günhan, B. (2010). Prospective mathematics teachers' views about using flash animations in mathematics lessons. International Journal of Human and Social Sciences, 5(3), 154-159.

Burke, K.A., Greenbowe, T. J., \& Windschitl, M.A. (1998). Developing and using conceptual computer animations for chemistry instruction. Journal of Chemical Education, 75(12), 1658-1661.

Büyüköztürk, Ş. (2010). Data analysis handbook for social sciences, Ankara: Pegem Academy Publications.

Byers, D.N. (1997). "So why use multimedia, the internet, and lotus notes? "Paperpresented at the Technology in Education Conference, San Jose, CA. (ERIC Document Reproduction Service No. ED413023)

Creswell, J.W. (2014). Research design: qualitative, quantitative and mixed methods approaches (4th ed.). Thousand Oaks, CA: Sage.

Cekbaş, Y., Yakar, H., Yıldırım, B., \& Savran, A. (2003). The effect of computer assisted education students. The Turkish Online Journal of Educational Technology, 2, 11.

Celen, F.K., Çelik, A., \& Seferoğlu, S.S. (2011, February). “Turkish education system and pisa results". Academic Informatics 2011, 2-4 Şubat 2011, İnönü University, Malatya. 
Celik, E. (2007). The effect of using computer aided animations to geography teaching skills of secondary education. Unpublished Master's Thesis, Marmara University, Institute of Education Sciences, İstanbul.

Cepni, S., Taş, E., \& Kose, S. (2006). The effect of computer-assisted material on students' cognitive levels, misconceptions and attitudes towards science. Computers $\mathcal{E}$ Education, 46, 192-205.

Cokluk Ö., Şekercioğlu G., \& Büyüköztürk Ş. (2010). Multivariate statistics spss and lısrel applications for social sciences. Ankara: Pegem Publishing.

Dalacosta, K., Kamariotaki-Paparrigopoulou, M., Palyvos, J.A., \& Spyrellis, N. (2009). Multimedia application with animated cartoons for teaching science in elementary education. Computers \& Education, 52, 741-748.

Daşdemir, İ., \& Doymuş, K. (2012). The effect of using animation on primary science and technology course students' academic achivement, retention of knowledge and scientific process skills. Pegem Journal of Education and Training, 2(3), 33-42.

Demircioğlu, H., \& Geban, Ö. (1996) Comparison of BDO and traditional problem solving activities in science teaching in terms of course achievement. Hacettepe Journal of Education Faculty, 12, 183-185.

DeVellis, R.F. (2003). Scale development theory and applications second edition. SAGE Publications International Educational and Professional Publisher, chapter 5: 60-96.

Ekici,E., Taşkın-Ekici, F. \& Kara, İ. (2012). Validity and reliability study of ICT self-efficacy perception scale for teachers. Pamukkale University Faculty of Education Journal, 31(1), 53-65.

Elmstrom Klenk, K. (2011). Computer animation in teaching science: effectiveness in teaching retrograde motion to 9th graders (Doctoral dissertation). Philosophy in Education, University of Rhode Island and Rhode Island College, Rhode Island.

Field, A. (2009). Discovering statistics using SPSS. (Third Edition). London: Sage.

Jereb, E., \& Smitek, B. (2006). Applying multimedia instruction in e-learning. Innovations in Education and Teaching International, 43(1), 15-27.

Gökhan, A. (2011). The effect of animation teaching on academic achievement in greenhouse gas effect in secondary education, acid rain and ozone depletion. Unpublished Master's Thesis, Cukurova University, Institute of Social Sciences, Department of Computer Education and Instructional Technology, Adana.

Jöreskog, K.G., \& Sörbom, D. (1996). LISREL 8 User's reference guide. Chicago: Scientific Software.

Karacop, A. (2010). The effects of animation and jigsaw techniques on understanding the subjects in electrochemistry and chemical bonding units. (Unpublished doctoral thesis, Graduate School of Sciences), Atatürk University, Erzurum.

Katircioglu, H., \& Gain, M. (2003). The effect of computer use on student achievement in general biology classes. Hacettepe University Faculty of Education Journal, 25, 127-134.

Kline, R.B. (2005). Principles and practice of structural equation modeling (2nd ed.). New York: Guilford. 
Laybourne K. (1998). The animation book: a complete guide to animated film-making from flip-books to sound cartoons to 3-d animation. N.Y., USA: Three Rivers Press.

Lewalter, D. (2003). Cognitive strategies for learning from static and dynamic visuals. Learning and Instruction, 13, 2, 177-189.

Lipeikiene, J., \& Lipeika, A. (2006). Animation tools of CAS for dynamic exploration of mathematics. Informatics in Education, 5, 87-96.

Loveless, A.M. (2003). The interaction between primary teachers' perceptions of 1ct and their pedagogy. Education and Information Technologies, 8(4), 313-326.

Mayer, R.E., \& Moreno, R. (2002). Animation as an aid to multimedia learning. Educational Psychology Review, 14(1), 87-99.

Mayer, R.E., \& Anderson, R.B. (1992). The instructive animation: Helping students build connections between words and pictures in multimedia learning. Journal of Educational Psychology, 84, 444-452.

Mayer, R.E. (2008). Applying the science of learning: Evidence-based principles for the design of multimedia instruction. American Psychologist, 63(8), 760-769.

Morgan, C.T. (1999). Psikolojiye Giriş (Çev.,H.Arıcı ve ark.). Meteksan, Ankara.

Najjar, L.J. (1996). Multimedia information and learning. Journal of Educational, Multimedia and Hypermedia, 5, 129-150.

Odabaşı, H.F., Akbulut, Y., Çuhadar, C., Dursun, Ö.Ö., Kabakçı, I., Kılıçer, K., Kurt, A.A.,

Şendağ, S., \& Tanyeri, T. (2006). Turkey basic education project: Baseline study on 1ct integration. Ankara: MEB Proje Koordinasyon Merkezi http://fodabasi.home.anadolu.edu.tr/docley6.swf

Ong, S.K., \& Mannan, M.A. (2004). Virtual reality simulations and animations in a web-based interactive manufacturing engineering module. Computers $\mathcal{E}$ Education, 43, 361-382.

Pallant, J. (2007). SPSS survival manual: A step by step guide to data analysis using spss for windows (3rd edition). Maidenhead: Open University Press.

Powell, J.V., Aeby, V.G., \& Carpenter-Aeby, T. (2003). A comparison of student out comes with and with out teacher facilitated computer-based instruction. Computers $\mathcal{E}$ Education, 40, 183-191.

Santos, R.S. (2009). Impact of flash animation on learning concept of matter among elementary students (Master thesis), Master of Science in Chemistry, University of Texas-Pan American.

Sümer, N. (2000). Structural equation models: Basic concepts and sample applications. Turkish Psychology Articles, 3(6), 49-74.

Szabo, M., \& Poohkay, B. (1996). An experimental study of animation, mathematics achievement, and attitude toward computer-assisted instruction. Journal of Research on Computing in Education, 28, 390-402.

Tabachnick, B.G., \& Fidell, L.S. (2007). Using multivariate statistics, 5th ed. Boston, MA: Allyn and Bacon. 
Tabbers, H.K., Martens, R.L., \& Van Merrienboer, J.J.G. (2004). Multimedia instructions and cognitive load theory: Effects of modality and cueing. British Journal of Educational Psychology, 74, 71-81.

Taber, K.S. (2002). Alternative conceptions in chemistry: Prevention, diagnosis and cure. London, UK: The Royal Society of Chemistry.

Taşçı, G., Yaman, M., \& Soran, H. (2010). Review of status regarding biology teachers' using new technologies in education. H. U. Journal of Education, 38, 267-278.

Tubin, D. Mioduser, D., Nachmias, R., \& Baruch, A.F. (2003). Domains and levels of pedagogical innovation in schools using ICT: Ten innovative schools in Israel. Education and Information Technologies, 8(2), 127-145.

UNESCO. (2006). Using ICT to develop literacy. UNESCO Bangkok.

URL-1. (2008). Board of Education. http://www.ttkb.gov.tr.

Watson, D. M. (2001). Pedagogy before technology: Re-thinking the relationship between ICT and teaching. Education and Information Technologies, 6(4), 251-266.

Yenice, N. (2003). The effect of computer-aided science education on students' science and computer attitudes. The Turkish Online Journal of Educational Technology, 2(12). 